\title{
Effects of the 2016 Kumamoto earthquakes on the Aso volcanic edifice
}

\author{
Yasuhisa Tajima ${ }^{1 *}$, Toshiaki Hasenaka ${ }^{2}$ and Masayuki Torii ${ }^{3}$
}

\begin{abstract}
Large earthquakes occurred in the central part of Kumamoto Prefecture on April 14-16, 2016, causing severe damage to the northern segment of the Hinagu faults and the eastern segment of the Futagawa faults. Earthquake surface ruptures appeared along these faults and on the Aso volcanic edifice, which in turn generated landslides. We conducted landform change analysis of the central cones of Aso volcano by using satellite and aerial photographs. First, we categorized the topographical changes as surface scarps, arc-shaped cracks, and linear cracks. Field survey indicated that landslides caused the scarps and arc-shaped cracks, whereas faulting caused the linear cracks. We discovered a surface rupture concentration zone (RCZ) formed three ruptures bands with many surface ruptures and landslides extending from the west foot to the center of the Aso volcanic edifice. The magmatic volcanic vents that formed during the past 10,000 years are located along the north margin of the RCZ. Moreover, the distribution and dip of the core of rupture concentration zone correspond with the Nakadake craters. We conclude that a strong relationship exists between the volcanic vents and fault structures in the central cones of Aso volcano.
\end{abstract}

Keywords: Kumamoto earthquake, Surface rupture, Central cones of Aso volcano, Vent location, Magma plumbing system

\section{Introduction}

Previous researches discussed the relationships among major active faults and the locations of volcanic vents created by the faulting. Nakamura (1969) indicated the existence of a strong relationship between regional stress fields and vent distributions observed on Fuji volcano, Izu-Oshima volcano, and Hakone volcano. Watanabe et al. (1979) suggested that two old cinder cones known as Akai and Omine that erupted large amount of lava flows at the western side of Aso caldera were located in two small extensional pull-apart structures, where two discontinuous right-lateral strike-slip faults had formed an echelon. Akai cinder cone at $148 \pm 7 \mathrm{ky}$, produced before the Aso- 2 caldera eruption at $141 \pm 5 \mathrm{ky}$, is located at the junction of Hinagu and Futagawa strike-slip faults, and Omine cinder cone at $90 \pm 4 \mathrm{ky}$, produced before the Aso-4 caldera eruption at $89 \pm 7 \mathrm{ky}$, is located in the

\footnotetext{
*Correspondence: yasuhisa79@gmail.com

${ }^{1}$ Nippon Koei Co., Ltd., 2-17-14, Higashisakura, Higashi-ku,

Nagoya 461-0005, Japan

Full list of author information is available at the end of the article
}

echelon part of the discontinuous Futagawa and Kitamukiyama strike-slip faults (Watanabe et al. 1979; Matsumoto et al. 1991; Watanabe 2001). Karakhanian et al. (2002) reported that some volcanoes in Armenia and its adjacent areas situated in a pull-apart basin bounded by strike-slip faults. Recently, Corti et al. (2013) indicated a strong relationship between the architecture of faults and volcanic cones in the African rift zone. Takahashi (1995) deduced that large-volume felsic volcanism related to the extensional stress field is likely a pull-apart structure within a large strike-slip fault. Mannen (2008) proposed that a pull-apart structure in Hakone caldera caused by a left lateral strike-slip faults. This study discusses the effects on the Aso volcanic textures and the role of magma supply systems created by actual major faulting of the Kumamoto earthquakes, instead of relationship of active faults or regional stress fields and volcanic structures.

\section{Outline of Kumamoto earthquakes and fault texture}

Futagawa faults extend about $64 \mathrm{~km}$ in length from the Uto Peninsula to Aso caldera and are categorized into 
three segments: Futagawa, Uto, and the northern coast of the Uto Peninsula (Headquarters for Earthquake Research Promotion 2002). The major earthquakes analyzed include the $M_{j} 7.3$ event that occurred along the eastern segment of the Futagawa faults on April 16, 2016, at 1:25 JST (Headquarters for Earthquake Research Promotion 2016). The Futagawa fault and related faults (Watanabe and Ono 1969; Watanabe et al. 1979) included in the Futagawa segment, which were oriented NE-SW on the western flank of Aso caldera (Fig. 1), affected the edifice of the central cones of Aso volcano. In the western region of Aso caldera, earthquake surface ruptures, hereafter referred to as surface ruptures, appeared on the Kitamukiyama ridge. These ruptures are mapped near the sites of previously the "Kitamukiyama" and "B" faults by Watanabe et al. (1979), the latter of which corresponds to a fault line south of Kitamukiyama in Fig. 2. Movement along these faults created numerous ground fractures observed in Minamiaso village at the western side of the central cones of Aso volcano (Fig. 2). In addition, many landslides occurred on the central cones of Aso volcano and its caldera walls.

In this study, we use the names or distributions of Aso volcano as described by Ono and Watanabe (1985), Watanabe (2001), and Miyabuchi et al. (2004b). Aso volcano includes a caldera and central cones. We use the fault textures described by Research Group for Active Tectonics in Kyushu (1989).

\section{Topographical analysis}

We conducted analysis of landform changes of Aso volcano by using a satellite photograph published by Google Earth (Google Earth @ 2016 ZENRIN 2016) on April 16, 2016, together with aerial photographs obtained on May 30 and 31 by the Geospatial Information Authority of Japan (2016). According to the photograph survey, landform changes were categorized as those associated with landslides and those related to faults (Fig. 2).

Using aerial photographs to determine whether cracks originated from faulting or landslides is a difficult task. First, we checked the typical landslide texture caused by Kumamoto earthquake on the central cones of Aso volcano based on Varnes (1978) and U.S. Geological Survey (2004) classifications. The Varnes (1978) classification scheme is based on materials, and landslide movements are categorized into three types: bedrock, debris, and earth. Very thick loose volcanic ash deposits and humic black soils (Kuroboku) are covering on the Aso volcanic edifice dispersed from the Nakadake crater (Ono et al. 1995). The landslides on the central cones of Aso volcano occurred mainly as earth slides, spread, and flow types based on the surface deposits composed of weathered fine volcanic materials and humic black soil (Fig. 3).
Earth slides, the most common landslide movements in this area, are divided into rotational and translational slides. The earth slide on the central cones of Aso volcano had a typical rotational shape with concave curve surfaces, flat heads, and transverse cracks or ridges (Fig. 3a). The typical translational slide exposed on the volcano has a flat surface and deposit (Fig. 3b). We identified both slides as black soil surfaces disturbed by movement with large main scarps and crown cracks surrounded by stationary green grass surfaces as "scarp of landslide" in Fig. 2. Earth flows occurred in some cases during the Kumamoto earthquake, as evidenced by the typical liquefied hourglass shape in the landslide occurring on the western flank of Okamadoyama volcano (O; Fig. 3c). We observed the earth flow as black soil surface scarp and dark-colored coating along the gully from the scarp with felled trees. We identified the scarps from earth flow as "scarp of landslide" in Fig. 2.

Creep-like deformation associated with many open cracks was noted at the tops of ridges or spurs along the slopes; however, these cracks did not exhibit main collapse bodies. We observed typical topographical textures on the Komezuka scoria cone (Fig. 3d), where partly circular cracks appeared on the outer rim of its summit crater. Several short cracks were opened along the slope dips from the top to the middle flanks. Additionally, we observed soil ripples around the top of the cone, which indicated that creep-like deformation occurred on the slopes when the cone moved during the earthquakes. We identified this type of crack and crown crack as "crack of landslide" in Fig. 2.

We noted a rare case of earth spread (Fig. $3 \mathrm{e}_{1}$ ) on flat terrain north of Yomineyama volcano $(\mathrm{Y})$. In this area, the main cracks, with a maximum width of $29 \mathrm{~cm}$, were extended $\mathrm{N}-\mathrm{S}$. The main crack bent to the west at a right angle to the down slope surface, and the main crack collapsed to the west with liquefaction occurring parallel to the cracks $\left(\right.$ Fig. $3 e_{2}$ ). Such topographical features indicated that the cracks were generated by landslides, which was similar to the process of lateral spread described by Varnes (1978). We were unable to identify this crack type in the aerial photographs. Therefore, we used this type crack as an example shown in Fig. $3 \mathrm{e}_{1}, \mathrm{e}_{2}$ which caused by faulting or landslide in field observation.

On the aerial photographs survey, we excluded cracks and scarps caused by landslides, which included earth slides, flows, and creep-like deformation. We identified the remained cracks indicating typically linear shape as "crack of earthquake" shown in Fig. 2 and ruptures caused by faulting by conducting field survey on the basis of this information. 


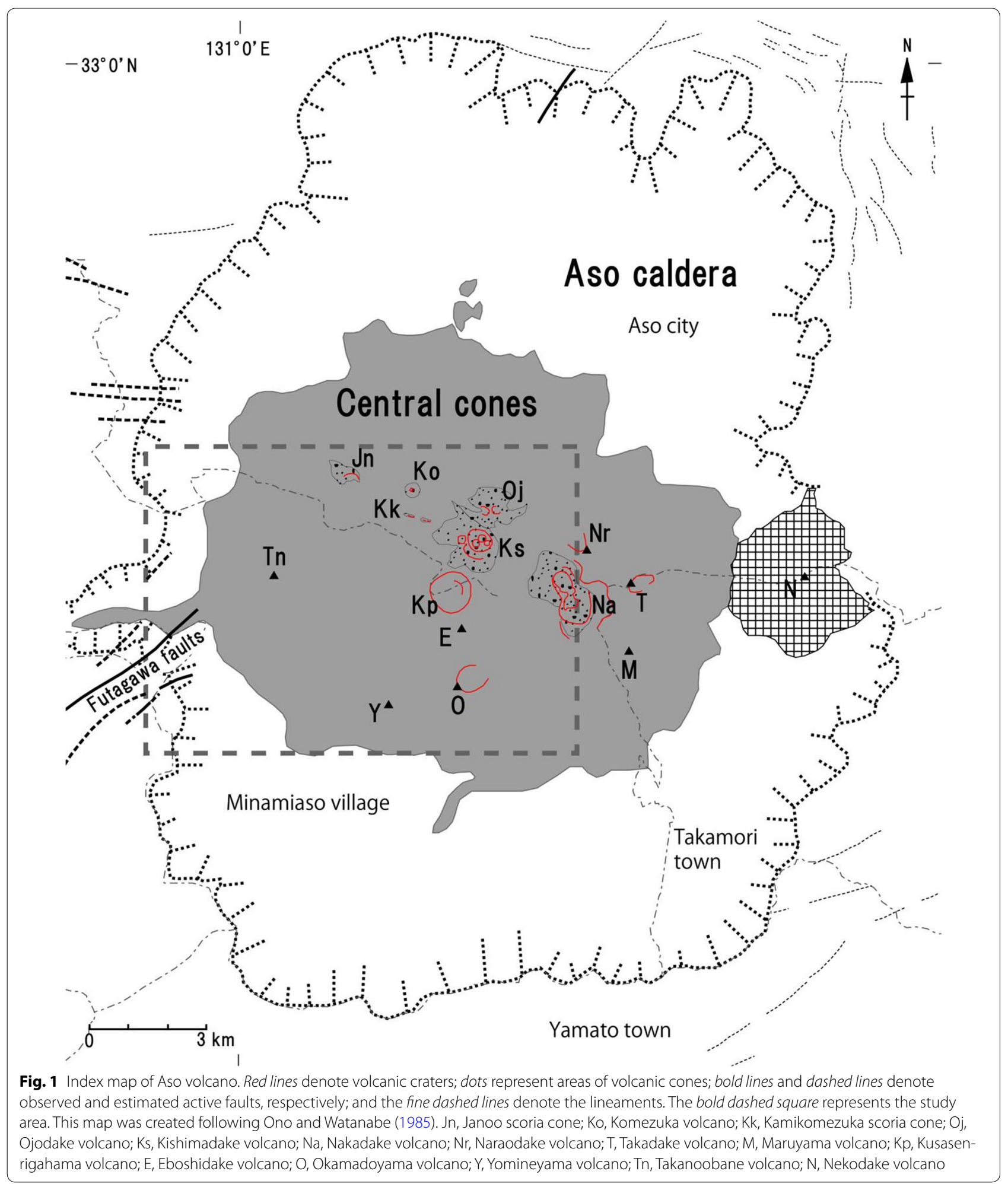

\section{Fault structures}

We found linear cracks on the flat planes or ridges on the volcanic edifice (Fig. 2). Surface ruptures oriented NE-SW of the Futagawa faults reached the Kawayo and
Kurokawa settlement areas on the west side of the Aso volcanic edifice (Shirahama et al. 2016). Additionally, many linear cracks with E-W to ESE-WNW orientation appeared between the southern edge of the Nagano 


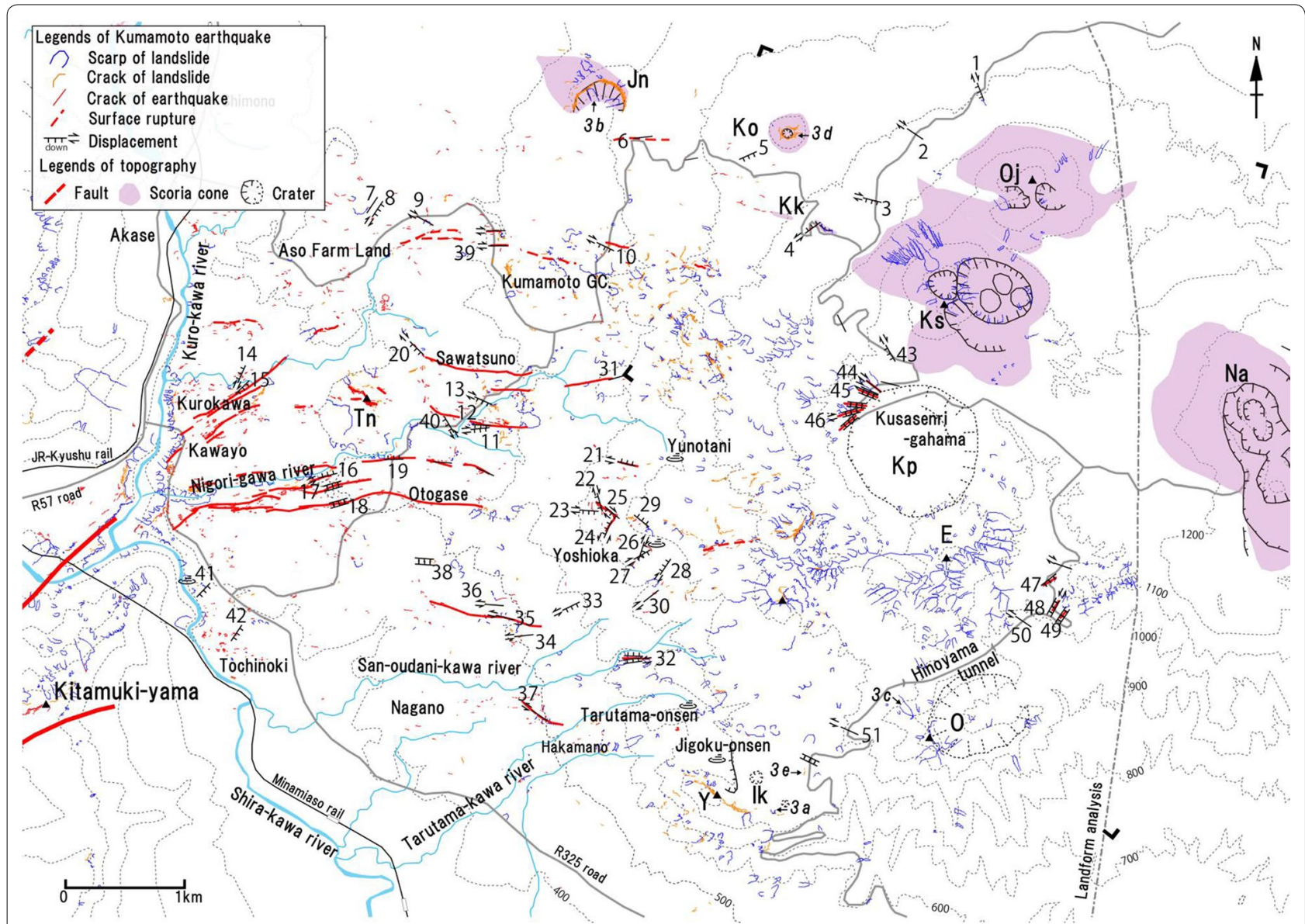

Fig. 2 Distribution of ruptures, cracks, and scarps created by Kumamoto earthquakes. Thick red lines around Kitamukiyama show active faults following Ono and Watanabe (1985). The black line (dashed) of craters denotes younger (older) craters of about 2-10 ky (Ono and Watanabe 1985; Miyabuchi and Watanabe 1997, 2000). 3a-3e indicate locations of landslides shown in Fig. 3. The abbreviations of volcanic names are the same as those shown in Fig. 1. Ik, Ikenokubo and Jigoku craters. L marks denote areas of aerial views in Fig. 8

settlement and the northern edge of Akase settlement, according to the observation of the Google Earth images. The locations and parameters such as numbers of surface ruptures with displacement confirmed by field survey are shown in Fig. 2 and in Table 1. These parameters are described below.

\section{Janoo to Komezuka}

In this area, short linear cracks appeared at intervals of 10-50 m. A small rupture was noted in an outcrop at the south side of Janoo scoria cone (Jn) having a strike and dip of $\mathrm{N}^{\circ} 4^{\circ} \mathrm{E}$ and $80^{\circ} \mathrm{S}$, respectively (Site 6). This small rupture broke the lava outcrop. In addition, we observed a right-slip rupture striking $\mathrm{N} 76^{\circ} \mathrm{W}$ on the road (Site 3) and many collapses that occurred on the Kishimadake volcano (Ks). These ruptures have similar strikes and intermittent rupture lines.

\section{Aso Farm Land to Kumamoto Golf Club}

Linear cracks formed a 200-400 m wide concentrated band marked by damaged houses and roads around Aso Farm Land, a resort facility. We mapped E-W and NESW cracks on the road and slopes around this region. At the eastern side of this area, the ruptures transected the road with mainly right strike-slips. Some surface ruptures cut through volcanic soil and tephra deposits at this location. We observed two small surface ruptures in a outcrop with strikes and dips of $\mathrm{N} 34^{\circ} \mathrm{E}$ and $80^{\circ} \mathrm{S}$, respectively (Sites 7 and 8, Fig. 4). Surface ruptures with right-lateral slip and $\mathrm{N} 61^{\circ} \mathrm{W}$ strike (Site 9) affected the houses at the southern part of Aso Farm Land. Many earthquake surface ruptures with E-W trend and many damaged houses appeared around the southern part of Site 9 and Site 39 with right strike-slips. Some surface ruptures extended to the Kumamoto Golf Course (GC) of Kumamoto Aso 


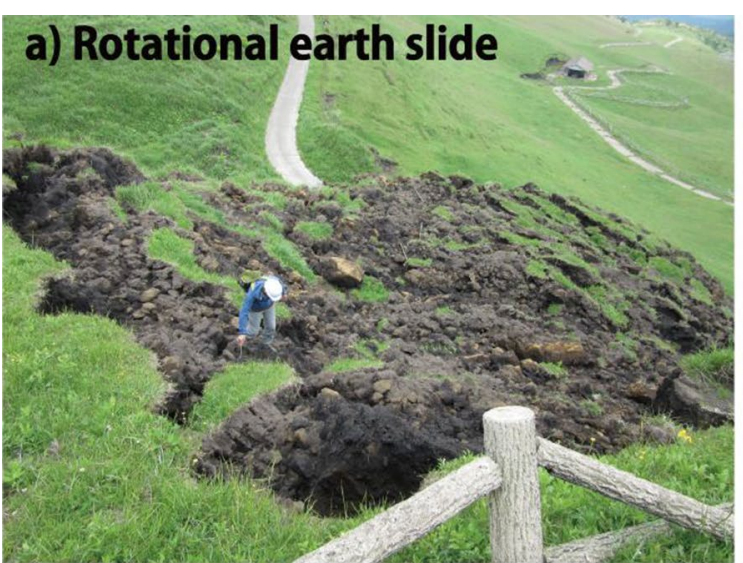

\section{b) Translational earth slide}

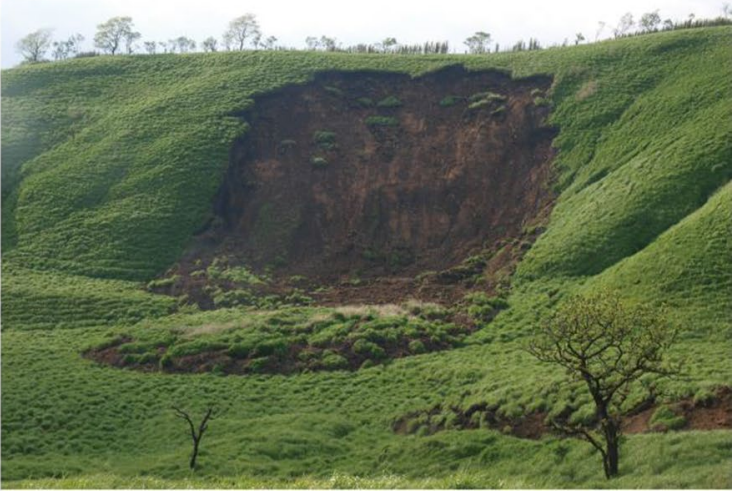

\section{c) Earth flow}
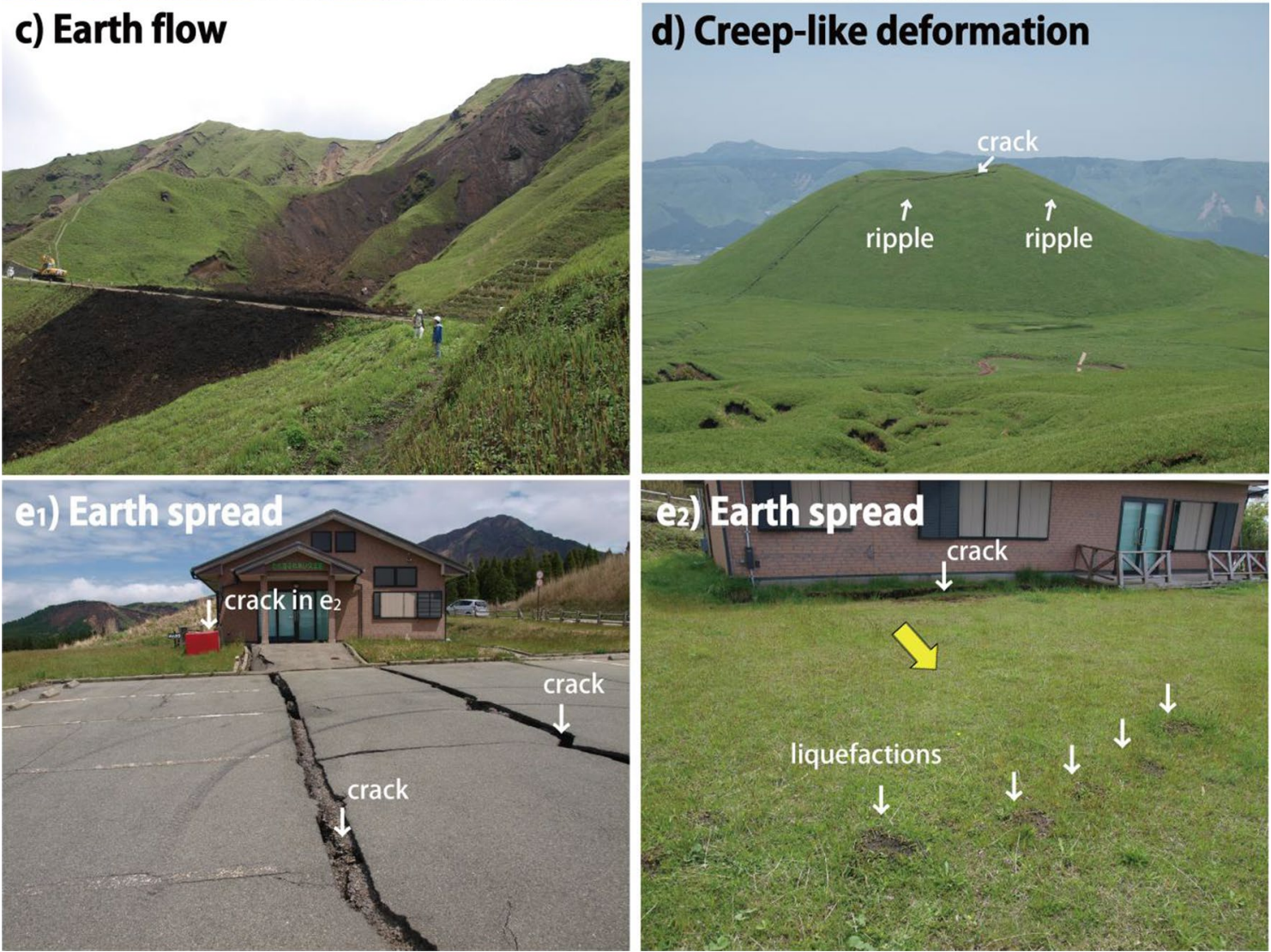

Fig. 3 Landslide type composed predominantly of fine deposits on the Aso volcanic edifice. a Rotational earth slide on Yomineyama volcano; b translational earth slide on Janoo scoria cone; c earth flow on the western flank of Okamadoyama volcano; d creep-like deformation on Komezuka volcano (scoria cone); $\mathbf{e}_{\mathbf{1}}, \mathbf{e}_{\mathbf{2}}$ earth spread in Yomineyama volcano including some liquefaction lines

Country Club. Earthquake ruptures trended NE-SW around Aso Farm Land and bent to WNW-ESE gently to the right around Kumamoto GC at Site 10.

\section{Kurokawa to Sawatsuno}

Many apparent linear cracks with $500 \mathrm{~m}$ in width appeared NE-SW trend in Kurokawa settlement. These cracks showed right-slip echelons. Some linear cracks extended to the Takanoobane-yama (Tn) from the west flank of the hill. Some linear cracks were found from the northwest flank of Takanoobane-yama to the southeast. In Sawatsuno settlement, an apparent surface rupture appeared the rupture surface with $\mathrm{N} 86^{\circ} \mathrm{W}$ strike and $84^{\circ} \mathrm{S}$ dip, and opening of $23 \mathrm{~cm}$ (Site 12, Fig. 5b). We found rupture displacement of $10 \mathrm{~cm}$ in right-lateral slip and $15 \mathrm{~cm}$ 
Table 1 List of parameters for rupture displacement

\begin{tabular}{|c|c|c|c|c|c|c|c|c|c|}
\hline \multirow{3}{*}{$\begin{array}{l}\text { Site No. } \\
1\end{array}$} & \multirow{3}{*}{$\begin{array}{l}\text { Appeared place } \\
\text { Road }\end{array}$} & \multicolumn{5}{|c|}{ Displacement } & \multicolumn{2}{|c|}{ Rupture surface } & \multirow{3}{*}{$\begin{array}{l}\text { Comments } \\
\text { Landslide occurred extended part }\end{array}$} \\
\hline & & \multicolumn{2}{|c|}{ Slip of strike ${ }^{* 1}$} & \multicolumn{2}{|c|}{ Slip of dip ${ }^{* 2}$} & \multirow{2}{*}{$\begin{array}{l}\text { Open } \\
-\end{array}$} & \multirow{2}{*}{$\begin{array}{l}\text { Strike } \\
\text { N21W }\end{array}$} & \multirow{2}{*}{$\begin{array}{l}\text { Dip } \\
-\end{array}$} & \\
\hline & & $\mathrm{R}$ & 2 & S & 1 & & & & \\
\hline 2 & Road & $\mathrm{R}$ & 3 & - & - & - & N56W & - & Landslide occurred extended part \\
\hline 3 & Road & $\mathrm{R}$ & 2 & S & + & - & N76W & - & Landslides occurred extended part \\
\hline 4 & Road & $L$ & + & $N$ & 3 & - & N54E & - & \\
\hline 5 & Outcrop & - & - & $S$ & + & - & N66E & - & \\
\hline 6 & Outcrop & - & - & - & - & - & N84E & $80 S$ & \\
\hline 7 & Outcrop, road & - & - & - & - & - & N34E & $80 S$ & \\
\hline 8 & Outcrop, road & $\mathrm{R}$ & 1 & S & 1 & - & N34E & $80 S$ & \\
\hline 9 & Road & $\mathrm{R}$ & 11 & - & - & - & N61W & - & \\
\hline 10 & Embankment & $\mathrm{R}$ & $(75)$ & $\mathrm{S}$ & (30) & - & N64W & - & Landslide occurred near site \\
\hline 11 & Ground, road & R & 10 & $S$ & 15 & - & N84E & - & \\
\hline 12 & Outcrop & - & - & $S$ & 0.5 & 23 & N86W & $84 S$ & \\
\hline 13 & Ground, road & $\mathrm{R}$ & 5 & $S$ & + & - & N66W & - & Earth slide occurred extended part \\
\hline 14 & Road & $\mathrm{R}$ & + & $\mathrm{N}$ & + & - & N24E & - & \\
\hline 15 & Rice field & - & - & $\mathrm{S}$ & 10 & - & N82E & - & \\
\hline 16 & Road & $L$ & 10 & $N$ & $25-30$ & 20 & $\mathrm{~N} 80 \mathrm{E}$ & - & \\
\hline 17 & Ground, road & - & - & $\mathrm{T}$ & $25-30$ & - & N74E & - & \\
\hline 18 & Ground, road & - & - & $\mathrm{T}$ & 28 & - & N74E & - & \\
\hline 19 & Ground & - & - & $N$ & 28 & 5 & N84E-86W & - & \\
\hline 20 & Road & $\mathrm{R}$ & 10 & $S$ & 20 & 5 & N46W & - & \\
\hline 21 & Ground, road & $L$ & 10 & $N$ & 5 & $2-3$ & N76W & - & \\
\hline 22 & Ground, road & $\mathrm{R}$ & $5-8$ & $\mathrm{~S}$ & 30 & $15-20$ & N16W & - & \\
\hline 23 & Ground, road & $\mathrm{R}$ & $2-3$ & $S$ & 20 & 20 & N86W & - & \\
\hline 24 & Ground & $L$ & 10 & $N$ & 15 & 30 & $\mathrm{~N} 24 \mathrm{E}$ & $85 N$ & \\
\hline 25 & Ground & $\mathrm{R}$ & 5 & $\mathrm{~S}$ & 20 & 50 & N50W & 635 & Rupture surface with N31W, 80S \\
\hline 26 & Ground, road & $\mathrm{R}$ & $2-3$ & $\mathrm{~S}$ & 1 & - & N24E & - & Spring and fumarole near this rupture \\
\hline 27 & Road & $\mathrm{R}$ & $1-2$ & S & $1-2$ & - & N60E & - & \\
\hline 28 & Road & $\mathrm{R}$ & $4-5$ & $N$ & + & $5-10$ & N34E & - & \\
\hline 29 & Ground & - & - & $\mathrm{N}$ & 20 & 30 & N51W & - & \\
\hline 30 & Ground & $\mathrm{R}$ & + & - & - & $3-10$ & N54-64E & - & \\
\hline 31 & Road & - & - & - & - & - & N74E & - & \\
\hline 32 & Road & $L$ & 3 & $\mathrm{~T}$ & $5-10$ & $5-10$ & N74E & - & \\
\hline 33 & Ground, road & $L$ & 5 & S & 15 & 15 & N64E & - & \\
\hline 34 & Road & $L$ & 5 & - & - & - & N84E & - & \\
\hline 35 & Rice field & $L$ & $(>50)$ & - & - & - & N76W & - & Earth slide occurred extended part \\
\hline 36 & Road & $L$ & 1 & - & - & - & N86W & - & \\
\hline 37 & Embankment & $L$ & $3-5$ & - & - & - & N56W & - & \\
\hline 38 & Road & - & - & $\mathrm{T}$ & + & - & N86W & - & \\
\hline 39 & Road & $\mathrm{R}$ & 20 & - & - & - & $(E W)$ & - & Strike was assumed from the map \\
\hline 40 & Ground, road & $L$ & 3 & S & $5-10$ & 5 & N31W & - & \\
\hline 41 & Ground, road & - & - & S & + & - & N44E & - & \\
\hline 42 & Road & - & - & S & $2-3$ & - & N34E & - & \\
\hline 43 & Road & $\mathrm{R}$ & + & $\mathrm{S}$ & + & - & N30W & - & Landslide occurred extended part \\
\hline 44 & Road, ground & $\mathrm{R}$ & 1 & - & - & 2 & N66W & - & \\
\hline 45 & Road, ground & - & - & S & 8 & 7 & N68W & - & \\
\hline 46 & Road, ground & $\mathrm{R}$ & 4 & $\mathrm{~T}$ & + & 5 & N74E & - & \\
\hline 47 & Road, ground & - & - & S & $0-5$ & - & $\mathrm{N} 52 \mathrm{E}$ & - & Landslide occurred extended part \\
\hline 48 & Road, ground & $L$ & + & $\mathrm{T}$ & + & + & N29E & - & Rupture appeared in scarp \\
\hline
\end{tabular}


Table 1 continued

\begin{tabular}{|c|c|c|c|c|c|c|c|c|c|}
\hline \multirow[t]{2}{*}{ Site No. } & \multirow[t]{2}{*}{ Appeared place } & \multicolumn{5}{|c|}{ Displacement } & \multicolumn{2}{|c|}{ Rupture surface } & \multirow[t]{3}{*}{ Comments } \\
\hline & & Sli & f strike ${ }^{* 1}$ & Slip & $f \operatorname{dip}^{* 2}$ & Open & Strike & $\overline{\text { Dip }}$ & \\
\hline$\overline{49}$ & Road, ground & - & - & $\mathrm{T}$ & 10 & - & N34E & - & \\
\hline 50 & Road & $\mathrm{L}$ & $2-3$ & - & - & - & N56W & - & \\
\hline 51 & Road & L & + & - & - & - & N66W & - & \\
\hline
\end{tabular}

A numerical value denotes centimeters. The bar and plus marks denote obscureness and a little value. Parentheses denote value included other influences

${ }^{*} 1$ : $R$, right strike slip; $L$, left strike slip

*2: N, north dip; S, south dip; T, subsidence
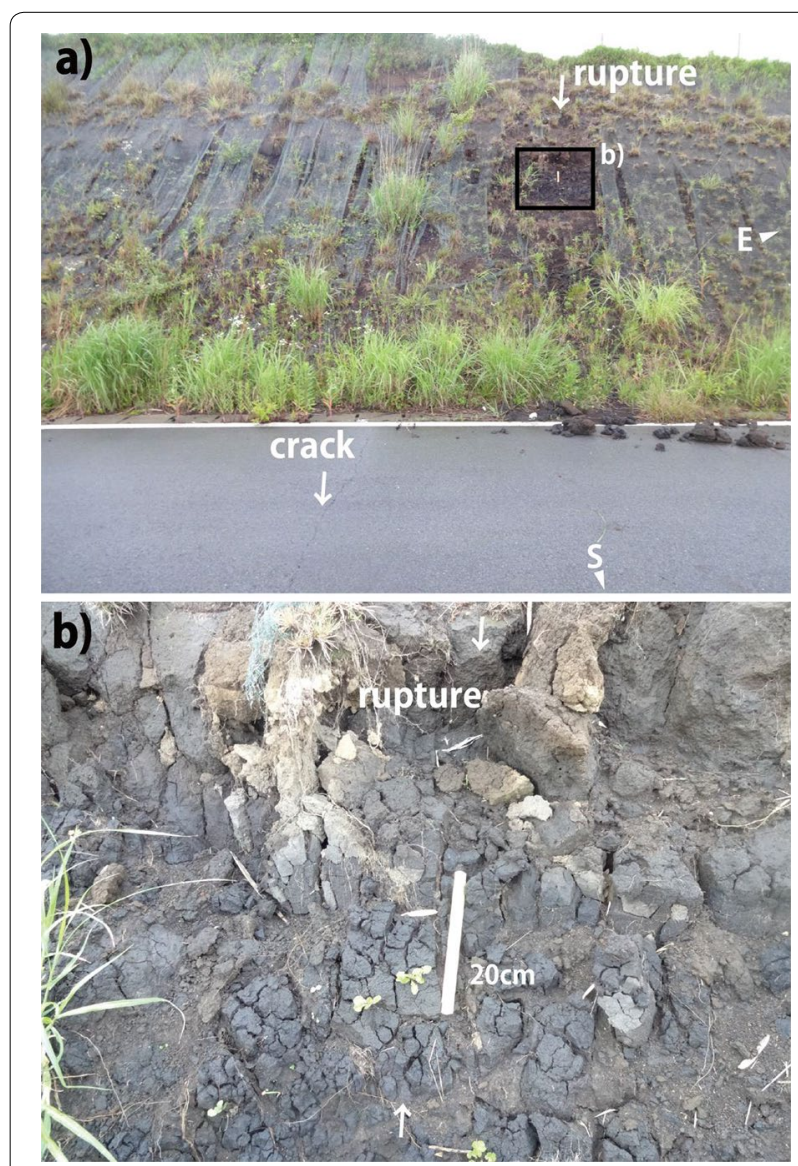

Fig. 4 Surface rupture near Aso Farm Land. a Earthquake rupture appearing in the outcrop at Site 8 ; b Rupture in outcrop observed at the surface with $\mathrm{N} 34^{\circ} \mathrm{E}$ strike and $80^{\circ} \mathrm{S}$ dip. Some ruptures exhibit the same strike and dip in this outcrop at Site 7

south side down with a N84ㄹ strike (Site 11, Fig. 5a). In this area, displacements of ruptures show right strikeslips and south dips dominant at Sites 20,11 and 13.

\section{Nigori-gawa to Otogase}

Clear linear cracks with echelon structures were interpreted along both sides of Nigori-gawa River by using
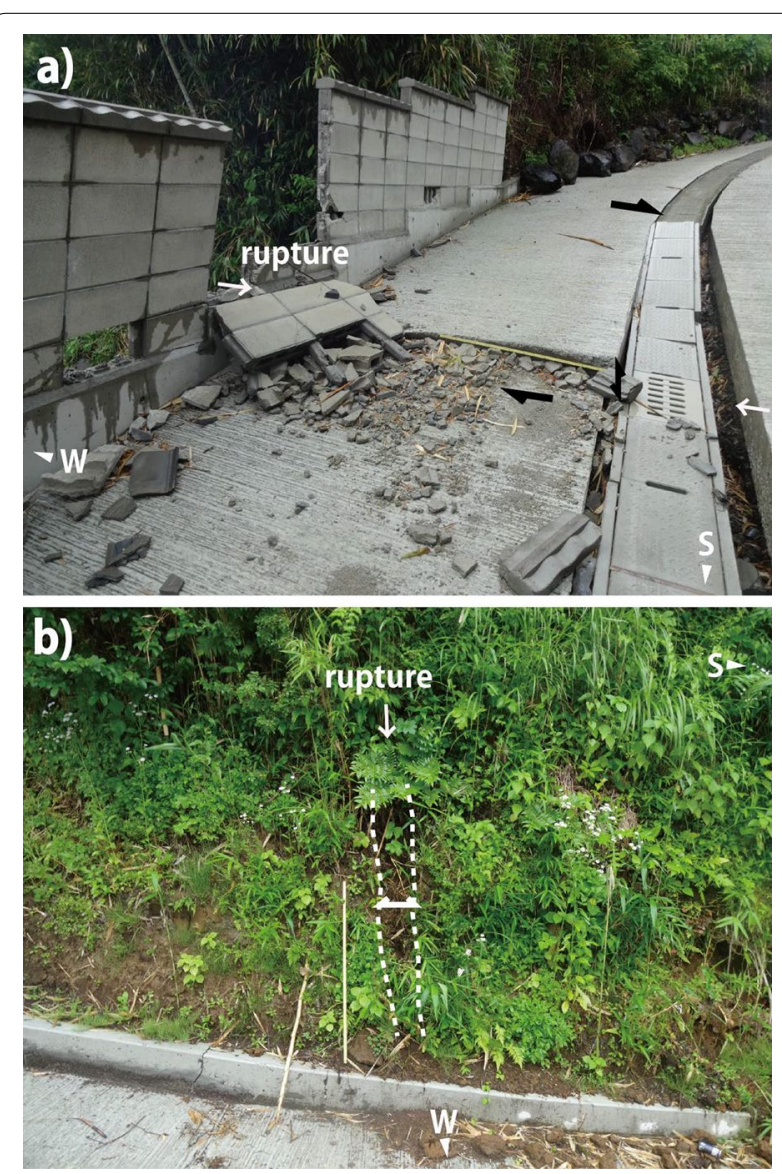

Fig. 5 Surface ruptures in Sawatsuno settlement. a Surface rupture with $10 \mathrm{~cm}$ right strike-slip and $15 \mathrm{~cm}$ south side down at Site 11; b surface rupture with $23 \mathrm{~cm}$ opening at Site 12 with N86 W strike and $84^{\circ} \mathrm{S}$ dip

Google Earth (Google Earth @ 2016 ZENRIN 2016) images. These cracks showed an ENE-WSW trend along the river and a bend gently to the south with a WNWESE trend around Otogase settlement. We confirmed two ruptures indicating north down displacements at Site 16 with left lateral slip and Site 19, and some subsidence ruptures created depressions on the road at Sites 17 and 18. 


\section{Nagano and Hakamano}

Some settlements in the Nagano and Hakamano area on the south flank of volcanic edifice included damaged houses, barns and collapsed slopes. In this area, we found a line of scars with the curvature of mowed rice fields and some collapses with a $N 76^{\circ} \mathrm{W}$ strike at Site 35 . The mowed rice in the other rice fields was generally in straight lines. We assumed that the curvature of the mowed rice and the line of collapse features were caused by left lateral faulting. In the Nagano area, we identified some left lateral displacements at Sites 34, 36,37 , and 38 on a road that strikes $N 84^{\circ} \mathrm{E}$ (Site 34). Many left lateral ruptures appeared at the southern side of the bridge in Heiseinagano-ohashi (Site 32). All of these features indicate that the ruptures are caused by ground movement of left lateral slip in the Nagano area.

\section{North Kusasenrigahama}

Many slope collapses appeared on the northwest flank of the Kusasenrigahama with more than seven surface ruptures $400 \mathrm{~m}$ in width on the road (Sites 44 to 46). These surface ruptures effected severely damages to the road. For example, surface rupture at Site 45 produced a subsidence rupture $115 \mathrm{~cm}$ in width on the ground adjacent to the road (Fig. 6a). The continuity part of this subsidence rupture with south side down was $8 \mathrm{~cm}$, and the opening and strike are $7 \mathrm{~cm}$ and $\mathrm{N} 68^{\circ} \mathrm{W}$, respectively (Fig. 6b). In this area, many surface ruptures indicate right slip of a few $\mathrm{cm}$.

\section{Yoshioka to north Hinoyama tunnel}

Surface ruptures appeared on the ridges of the northern Yoshioka fumaroles (Fig. 7a) occurring as fractures $50 \mathrm{~cm}$ wide with right-lateral slip of $5 \mathrm{~cm}$ and a dip of $20 \mathrm{~cm}$ (Site 25, Fig. 7c). With an unobstructed view, we were able to observe a $\mathrm{N} 50^{\circ} \mathrm{W}$ strike and $63^{\circ} \mathrm{S}$ dip. This rupture turned perpendicularly to the south with a N24 ${ }^{\circ} \mathrm{E}$ strike and an $85^{\circ} \mathrm{N}$ dip over the ridge (Site 24, Fig. 7b). In this area, two types of ruptures were observed as E-W line (Site 21 and 23) and ruptures with bend shaped distribution (Sites 22, 24 and 25). We confirmed north dip of rupture at Sites 21 and 29.

Some surface ruptures appeared on the road at north Hinoyama tunnel (Sites 47 to 50). We found a surface rupture at Site 47 with a $N 52^{\circ} \mathrm{E}$ strike and subsidence on the road. The subsidence ruptures at Sites 48 and 49 seem to extend to Nakadake volcano $(\mathrm{Na})$ with strikes of $\mathrm{N} 29^{\circ} \mathrm{E}$ and $\mathrm{N} 34^{\circ} \mathrm{E}$, respectively.

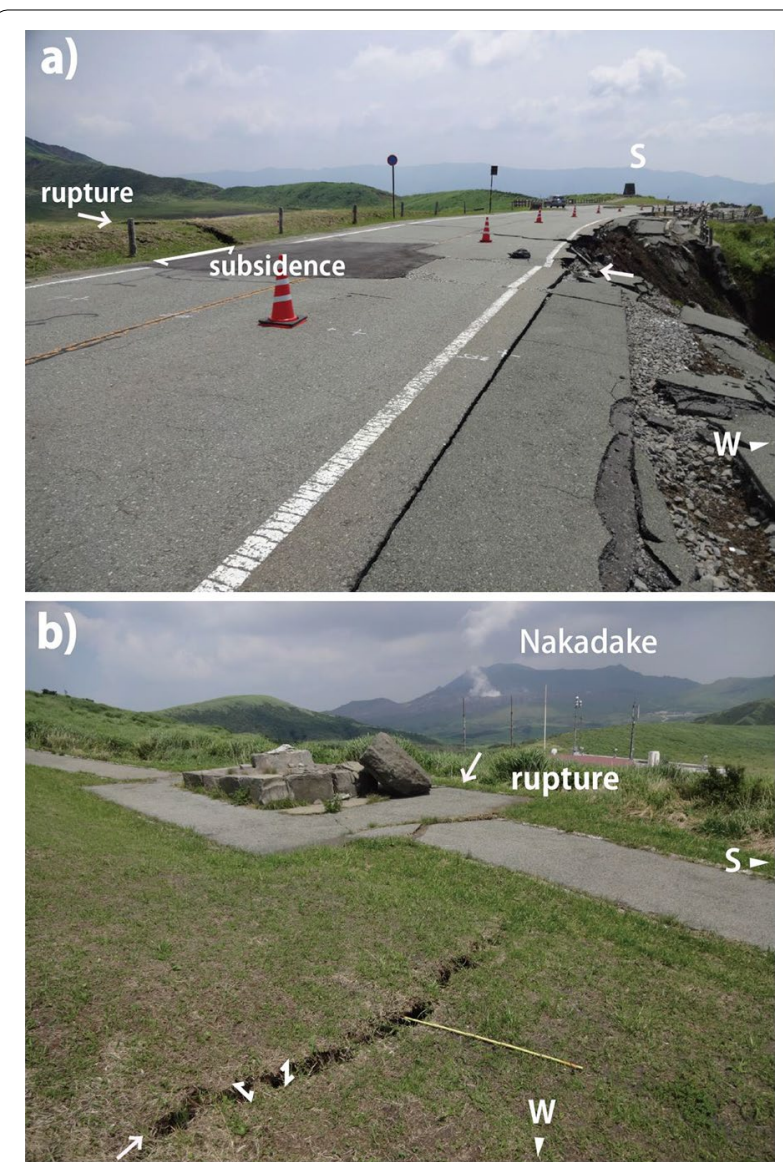

Fig. 6 Surface rupture at north Kusasenrigahama. a Surface rupture appearing at Site 45 . The subsidence rupture created negative values of $12 \mathrm{~cm}$ on the north side and $20 \mathrm{~cm}$ on the south side. $\mathbf{b}$ Subsidence rupture in a showing change to linear rupture continuity. The displacement is $8 \mathrm{~cm}$ south side down and $7 \mathrm{~cm}$ at the opening

\section{Relationship of faulting and landslides}

We identified some association between the ruptures and landslides. Many landslides occurred at the southern flank of Eboshidake (E) (Fig. 8). We confirmed the existence of surface ruptures around the north Hinoyama tunnel area (Sites 47-50). The surface rupture at Site 47 (Fig. 9b) related to many earth slides along the gully; rupture at Site 48 (Fig. 9c) exposed in the scarp of the slide. These two ruptures indicate a strong relationship between faulting and landslides in addition to ground motion.

It the northern part of Sawatsuno settlement, the surface rupture at Site 13 (Fig. 9a) related to large earth slides typically $100 \mathrm{~m} \times 300 \mathrm{~m}$ in width and length, respectively. The large landslide on the western flank of Takanoobane volcano (Miyabuchi 2016) situated near linear cracks. We found similar cases of landslides caused by faulting, which indicated a strong relationship 

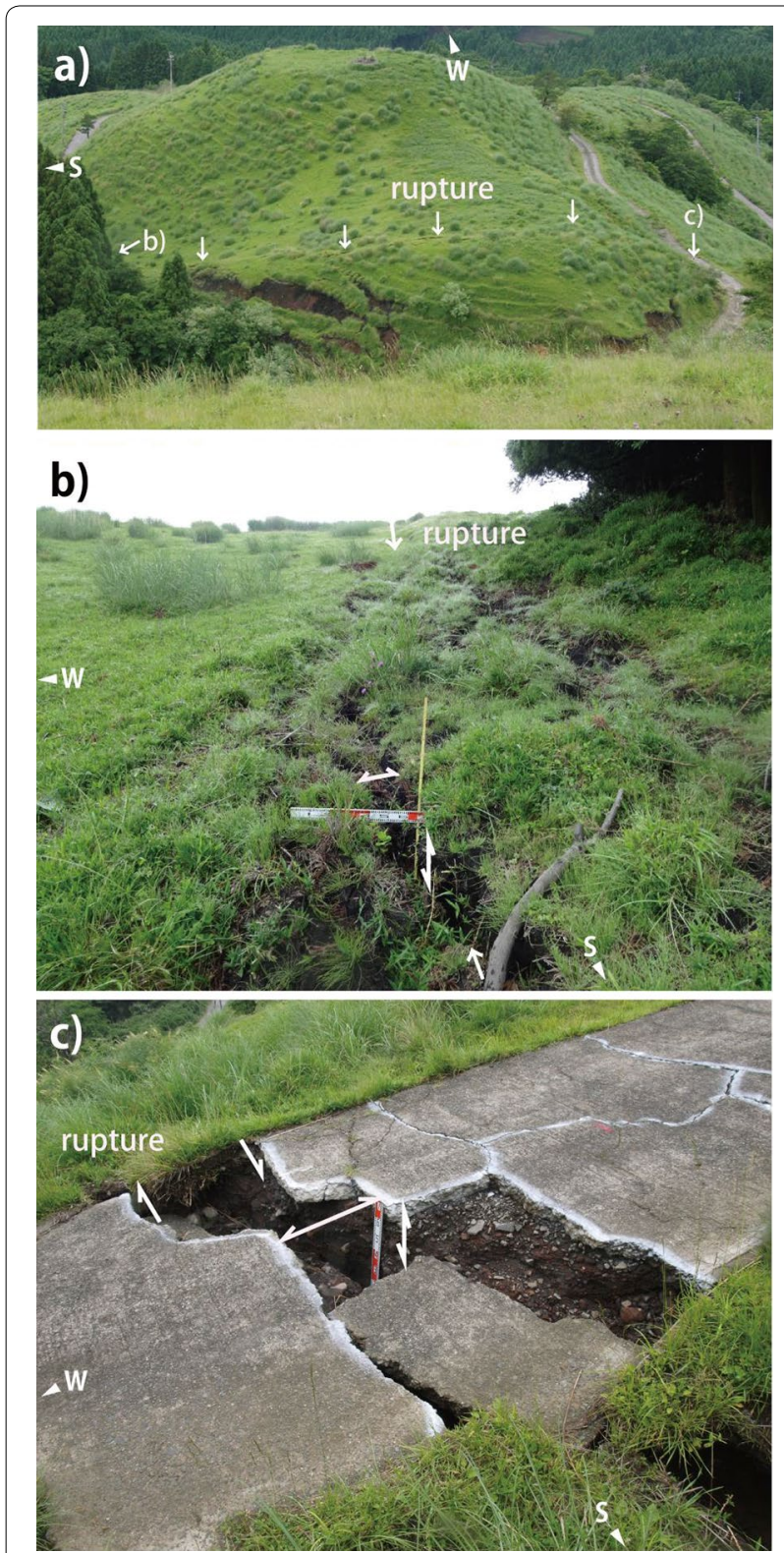

Fig. 7 Bended rupture at north Yoshioka. a Surface rupture that appears on the ridge near Yoshioka; $\mathbf{b}$ surface rupture at Site 24 with left strike-slip showing $\mathrm{N} 24^{\circ} \mathrm{E}$ strike and $85^{\circ} \mathrm{N}$ dip with $30 \mathrm{~cm}$ opening and $15 \mathrm{~cm}$ west side down. c Surface rupture at Site 25 showing a $\mathrm{N} 50^{\circ} \mathrm{W}$ strike and a $63^{\circ} \mathrm{S}$ dip. The surface with $5 \mathrm{~cm}$ right strike-slip shows a N31 ${ }^{\circ} \mathrm{W}$ strike and an $80^{\circ} \mathrm{S}$ dip with $50 \mathrm{~cm}$ opening and $20 \mathrm{~cm}$ west side down

between faulting and landslides. The surface ruptures appeared from Aso Farm Land to Kumamoto GC. Farther to the east, we found numerous landslides on the northwest flank of Kusasenrigahama volcano and surface ruptures on the road at Sites 43-46 (Fig. 8). We assume landslides triggered by ground motion and rupturing on central cones of Aso volcano.
In the east Komezuka area, three small ruptures appeared on the road between Ojodake and Kishimadake volcanoes. The rupture at Site 1 had a strike of $\mathrm{N} 21^{\circ} \mathrm{W}$ with a $2 \mathrm{~cm}$ right-lateral slip and a small collapse toward the eastern extension of the rupture (Fig. 8). The ruptures at Sites 2 and 3 were right-lateral slip with a $\mathrm{N} 56^{\circ} \mathrm{W}$ strike and $3 \mathrm{~cm}$ slip and a $\mathrm{N} 76^{\circ} \mathrm{W}$ strike and $2 \mathrm{~cm}$ slip, respectively (Table 1 ). We assume that the collapses on the western flanks of Ojodake and Kishimadake relate to these ruptures (Fig. 8).

\section{Ruptures concentration zone}

Many landslides and surface ruptures appeared in a concentration zone trending E-W at 5-6 km in width up to the boundary of our analysis on the western side of the central cones of Aso volcano. Earthquake ruptures and landslides generated by the Kumamoto earthquakes on the Aso volcanic edifice is described as a ruptures concentration zone with landslides (RCZ; Fig. 10).

The surface ruptures and linear cracks on the southern area of Komezuka volcano (Ko) were rotated $20^{\circ}$ clockwise with respect to the Janoo area. These ruptures appeared to be continuous at intervals and have similar orientation (Fig. 10). Many landslide cracks that formed through creeping deformation appeared on the summit crater ridges of Janoo and Komezuka scoria cones. We assumed that the rupture in south Janoo affected these scoria cones with strong ground motion. In this area, the cracks of earthquake and scarps or cracks of landslide appeared fewer than the north Kusasenrigahama and south Eboshidake areas. Therefore, we define this margin of the RCZ as the north margin of the RCZ (NM-RCZ). The line extending from the Janoo scoria cone to Komezuka volcano forms the northern limit of the RCZ.

The continuation of surface ruptures around Aso Farm Land from the Kurokawa was not clear. However, in the Aso Farm Land area, cracks of earthquake formed a concentrated zone $200-400 \mathrm{~m}$ in width marked by some ruptures and damaged houses or roads. In the north Kusasenrigahama area, we observed a ruptures zone on the ridge and many collapses from the Aso Farm Land and Sawatsuno area. We use the term "rupture band" to refer to the concentrated surface ruptures and landslides occurring within a few hundred meters. The rupture band from Aso Farm Land to north Kusasenrigahama, defines as the North Aso (Aso-N) rupture band (Fig. 10), changes its direction from E-W around Aso Farm Land to WNW-ESE around north Kusasenrigahama. The Sawatsuno area is traversed by a NW-SE rupture band manifested as surface ruptures and many landslides within about $400 \mathrm{~m}$ in width. These structures are concentrated in a band defined as the Center Aso (Aso-C) rupture band. We assume that this rupture band diverges 


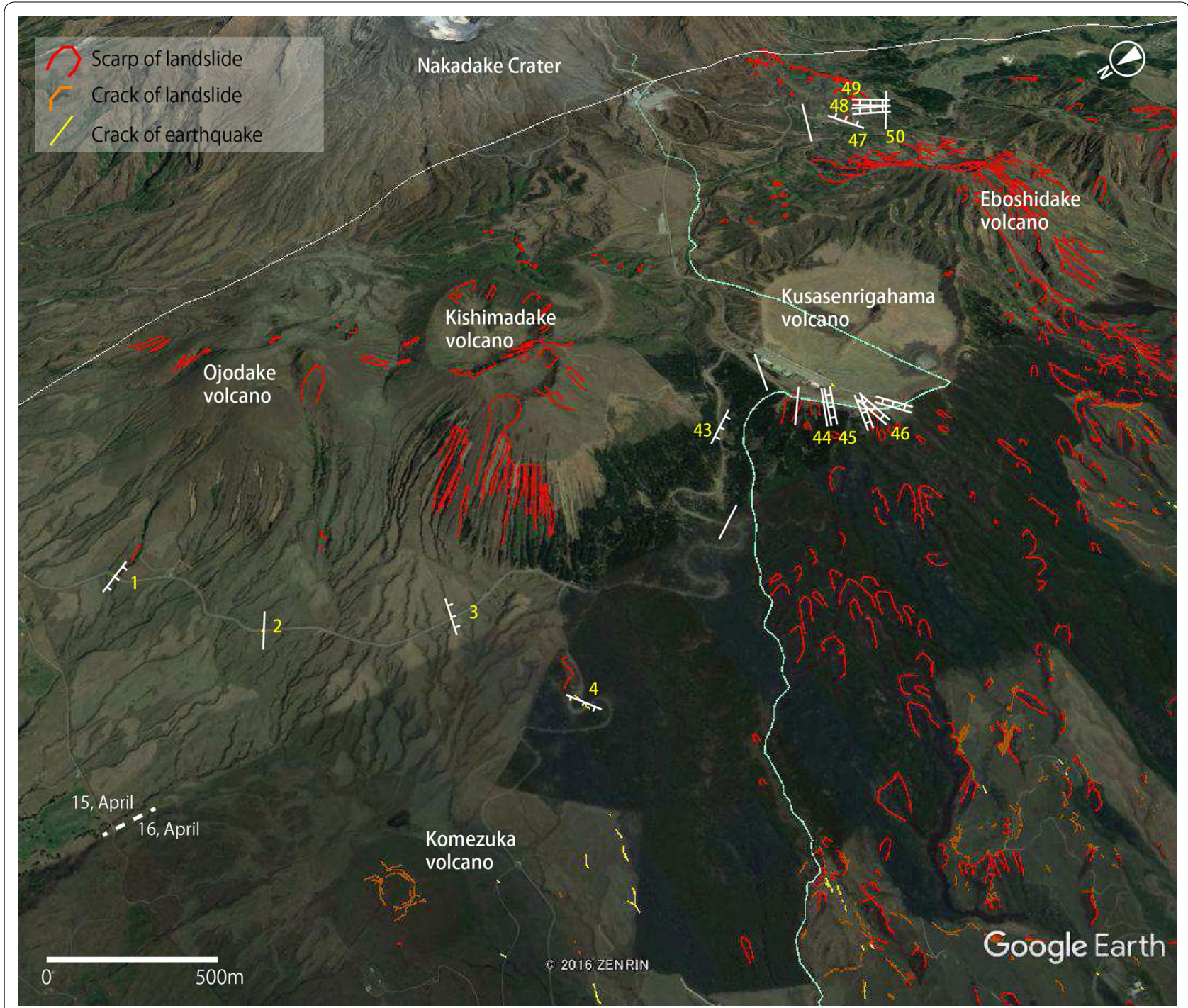

Fig. 8 Distribution of surface ruptures and landslides based on images of Google Earth (Google Earth @ 2016 ZENRIN 2016) and Geospatial Information Authority of Japan (2016). The landslides are concentrated from north Kusasenrigahama to south Ebosidake in this aerial view. The two bands of concentrated landslides occur around the concentrated surface ruptures at the north Kusasenrigahama and east Eboshidake volcano regions

from the Aso-N rupture band and rejoins it later because the surface ruptures and landslide zone distribution extend to north Kusasenrigahama.

Many ruptures around the Yoshioka and landslides on the southern flank of Eboshidake form a band from Nigori-gawa to the south flank of Eboshidake, which is referred to as the South Aso (Aso-S) rupture band (Fig. 10).

The surface ruptures appeared from Nagano to Heiseinagano-ohashi and from Hakamano to Jigokuonsen. This area has fewer ruptures than those in the south Eboshidake region. We define this margin of the $\mathrm{RCZ}$ as the south margin of the RCZ (SM-RCZ); the
Hakamano area and Yomineyama form the boundary of the southern limit of the RCZ (Fig. 10).

The central part of the RCZ is composed of Aso-N, Aso- $\mathrm{C}$, and Aso-S rupture bands and defined as the core of the RCZ (C-RCZ). Aso-S rupture band extends along the Nigori-gawa River, which has a straight gully with a cliff of north side down topography indicating an active fault. We assume that hidden fault relates ruptures from Yoshioka to the north Hinoyama tunnel and many landslides in the southern flank of the Eboshidake area. The Aso-N.C rupture bands consist mostly of south down normal and right strike-slip displacements. The Aso- $\mathrm{C}$ rupture band extends mainly at the north side of 

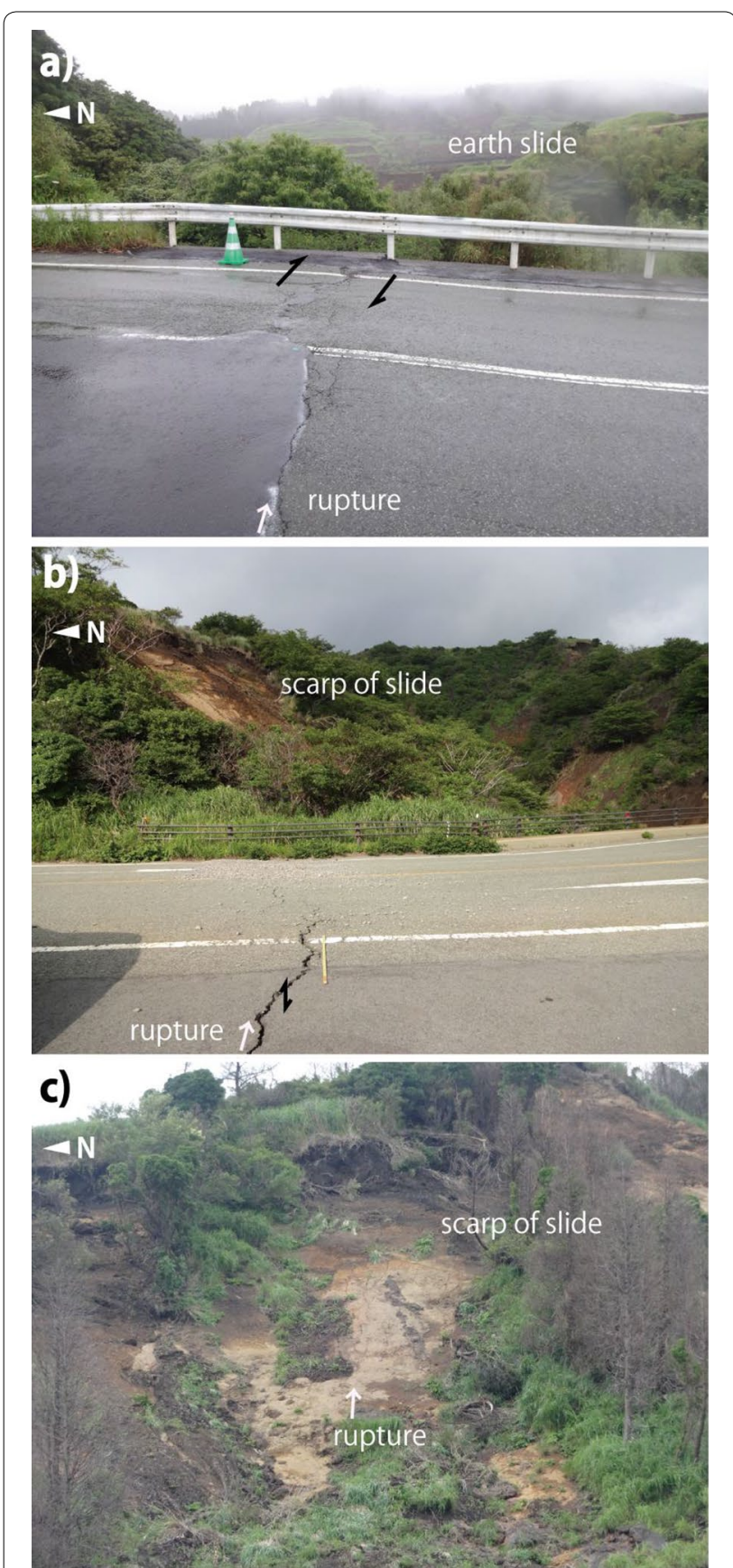

Fig. 9 Relationship of surface rupture and landslides. a Surface rupture with $5 \mathrm{~cm}$ right strike-slip extending to earth slides at Site 13 . b Surface rupture with maximum $5 \mathrm{~cm}$ south side down extends to slides at north Hinoyama tunnel at Site 47. c Surface rupture in the scarp of slide at north Hinoyama tunnel at Site 48

Takanoobane-yama along an E-W trending obscure cliff indicating the possibility of an active fault. These rupture bands do not show the narrow lines of faults. A possible explanation is that the ruptures widened near the surface with thick, soft volcanic sediments and steep volcanic topography. Alternatively, the parallel ruptures show substantial evidence of extensional faulting in this case.

\section{Younger volcanic vents along the faults}

Basaltic magma eruptions produced during the past 10,000 years were observed at Kishimadake volcano (4 cal. ky; Miyabuchi and Watanabe 1997; Miyabuchi 2009), Ojodake volcano (3.6 cal. ky; Miyabuchi and Watanabe 1997; Miyabuchi 2009), Komezuka volcano, Kamikomezuka scoria cone (3.3 cal. ky; Miyabuchi 2010). Janoo scoria cone in 4.9-4.3 ky and pumice fall eruption occurred at Janoo scoria cone in $4.1 \mathrm{cal}$. ky (Miyabuchi 2017). These age data were obtained from organic soils under each tephra that was expected to block the younger carbon contamination (Okuno and Nakamura 2003; Okuno 2011) from the layers above; these magmatic vents including craters are distributed along the NM-RCZ. The aforementioned features indicate a strong relationship between the locations of magmatic vents and the NM-RCZ.

Nakadake volcano began erupting 22-21 ky and generated frequently eruptions until the present (Miyabuchi et al. 2004a). The main craters of Nakadake elongate from south No. 4 to north No. 1 (e.g., Ono and Watanabe 1985). Surface ruptures related to the Aso-N and Aso-C (Aso-N.C) rupture bands appeared at the north Kusasenrigahama area and reached approximately $3 \mathrm{~km}$ from No. 1 Nakadake crater. Aso-N.C rupture bands seem to extend toward northern part of Nakadake craters. Surface ruptures related to the Aso-S rupture band reached approximately $2 \mathrm{~km}$ from No. 4 Nakadake crater. Aso-S rupture band seems to extend toward southern part of Nakadake craters. These features indicate a relationship between the locations of Nakadake craters and C-RCZ including the Aso-N.C rupture bands and Aso-S rupture band.

Yoshioka Hot Spring, known as a highly fumarolic area extending NE-SW, increased fumarole activity in 2005 (Terada et al. 2007). In this area, many surface ruptures appeared on the ground (Fig. 11). Moreover, we found a type of rupture having NE-SW strikes at Site 26 that extended to the hot water source of the Yoshioka hot spring shown by Terada et al. (2007). Geospatial Information Authority of Japan (1994) showed possible landslides in the Yoshioka fumarole area. Some ruptures at Sites 26-28 had NE-SW strikes and were located within the landslide area. On the contrary, the earthquake ruptures at Site 25 with NW-SE strike and those at Sites 24 and 30 with NE-SW strikes situated outside of the landslide (Fig. 11). We infer that extensional faulting produces these ruptures to the west during the Kumamoto earthquakes. The minimum total width of the E-W opening is $50 \mathrm{~cm}$ around the Yoshioka fumarole area. We 


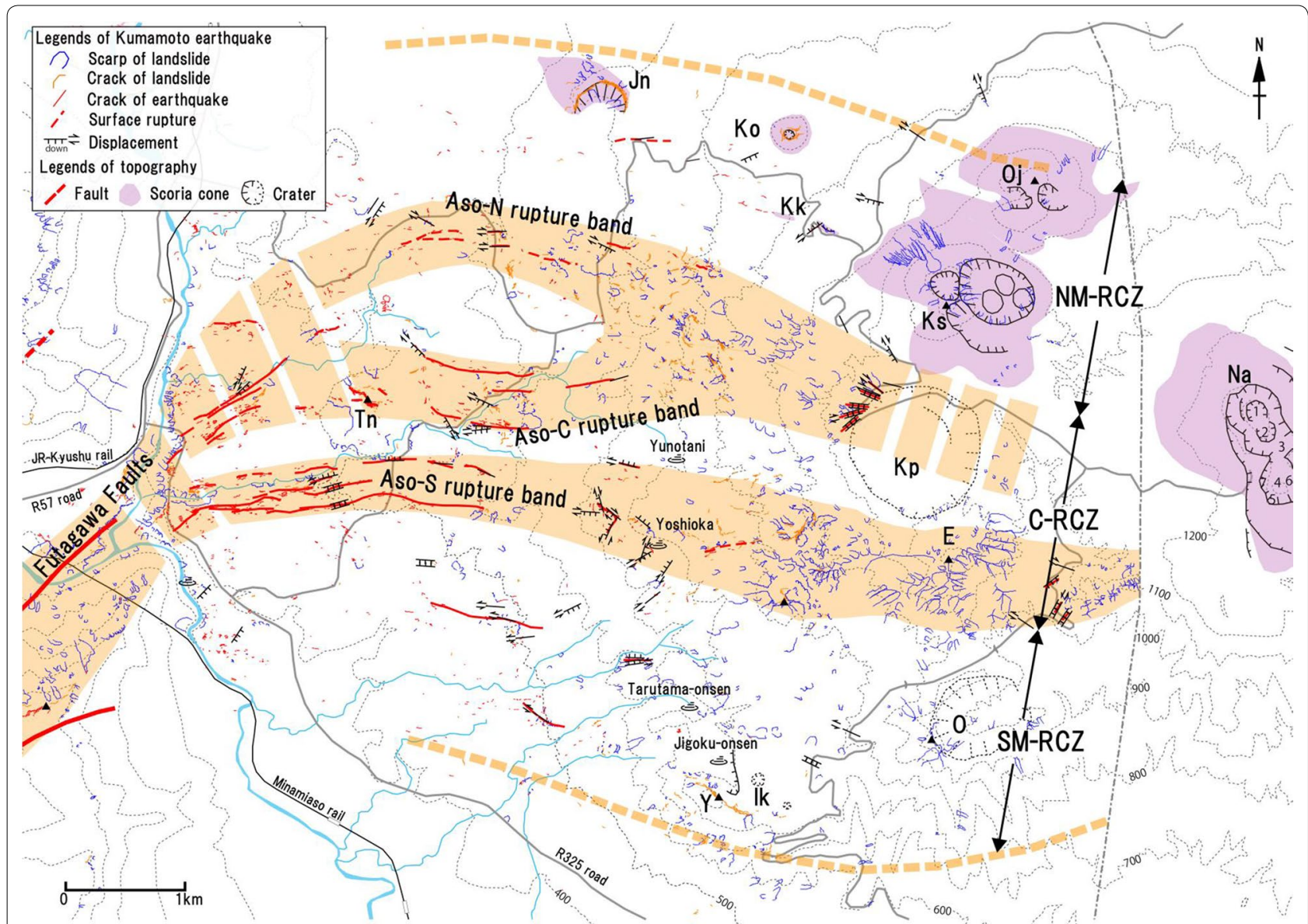

Fig. 10 Distribution map of ruptures concentration zone (RCZ) with landslides concentrated on Aso volcanic edifice. Orange bands denote the rupture band, and the dashed orange line denotes the RCZ. C-RCZ: core of RCZ; NM-RCZ: northern margin of RCZ; SM-RCZ: southern margin of RCZ. Nakadake crater numbers 1-7 are shown in Ono and Watanabe (1985)

consider that extensional process of the bended rupture that displacement likely normal fault caused by the earthquakes plays an important role in creating the Yoshioka fumarole.

Phreatic eruptions occurred at Jigoku-onsen in 6.4$5.0 \mathrm{cal}$. ky (Miyabuchi and Watanabe 2000) and at the tuff ring of Ikenokubo (Ik) (Geospatial Information Authority of Japan 1994) in the SM-RCZ. Phreatic eruption also occurred at Yunotani in A.D. 1816 (Ikebe and Fujioka 2001) in the Aso-S rupture band. We consider these geothermal activities including Yoshioka fumarole and phreatic eruptions vents relate Aso-S rupture band and SM-RCZ.

\section{Magma plumbing system with faults}

We assume that movement of C-RCZ has produced the recent magma discharge crater of Nakadake. For example, we observed a dip of $84^{\circ} \mathrm{S}$ in the Aso-C rupture band at Site 12. A dip of about $85^{\circ}$ southward maintained underground caused the Aso-N.C rupture bands could have extend toward the south side of -30 to $-20 \% \mathrm{~S}$ velocity perturbation named LD at a depth of about $6 \mathrm{~km}$ below mean sea level (msl) beneath Kusasenrigahama, as reported by Sudo and Kong (2001). The LD low-velocity region is considered to be a magma chamber in the partially molten magma system of Aso volcano (Sudo and Kong 2001). Therefore, we assume that the Aso-N.C rupture bands could not have reached a depth of more than -2 or $-3 \mathrm{~km}$ msl beneath Kusasenrigahama because rocks at this depth experience plastic deformation as a shallow magma storage region, which is not conducive for volcanic earthquakes (e.g., Japan Meteorological Agency 2013). Aso-N.C rupture bands at a depth of -2 to $-3 \mathrm{~km}$ msl are accordance with the narrow low-velocity part above the magma chamber. Aso-S rupture band was observed north side down displacements, but we did not found the dips in the outcrop. If the dip of the Aso-S rupture band is similar to that of the Aso-N.C rupture bands to north dip, the Aso-S rupture band is similar situation as Aso-N.C rupture bands. 


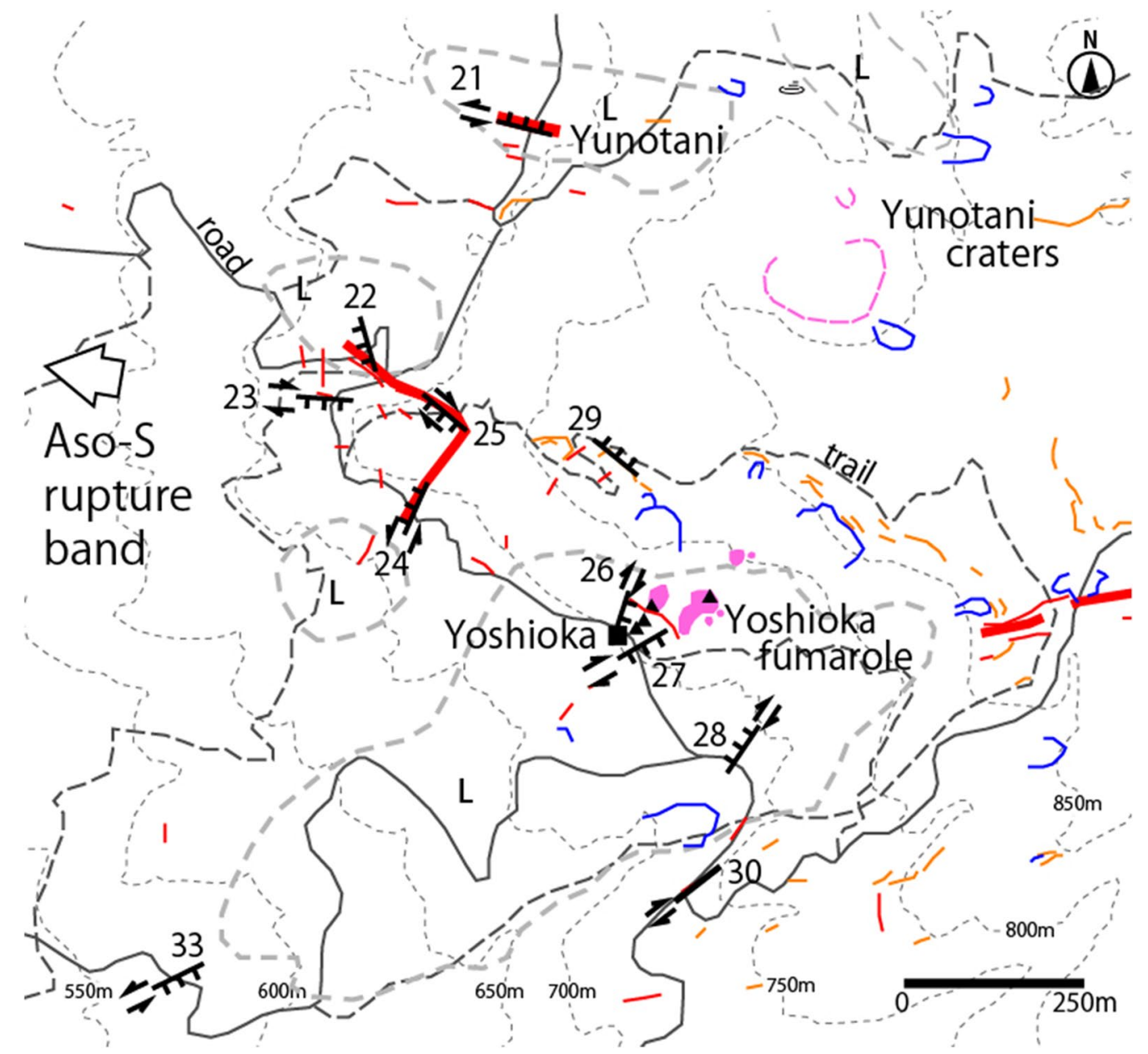

Fig. 11 Relationship of ruptures distribution and fumaroles shown by a geomorphological map of the area around Yoshioka fumarole. The legends of Kumamoto earthquake are shown in Fig. 10. Marks denote areas of damaged plants (pink), fumaroles (solid triangles), and hot water sources (solid squares) shown in Terada et al. (2007). Grey dashed line marked by L denotes possibility of landslide topography prior to the Kumamoto earthquake, as shown in Geospatial Information Authority of Japan (1994). The Yunotani craters are shown in Ikebe and Fujioka (2001)

We discuss below plumbing system using C-RCZ. In the Futagawa faults propagating with right strike-slip and north dip of normal fault from the western side of Aso caldera, three rupture bands began around Kawayo settlement. These rupture bands probably reached the western margin of the magma storage region beneath Kusasenrigahama (Fig. 12). The Aso-N.C rupture bands altered to shallow-depth faults at the east side of Kusasenrigahama. Because Aso-N.C rupture bands suddenly became obscure in the east Kusasenrigahama region (Fig. 10). The Aso-S rupture band appeared on east side of Ebishiodake. It was assumed effect to Aso-S rupture band from magma storage region was lower than Aso-N.C rupture bands. We assume that this fault shallowing process across the magma storage region is important for causing the magma to travel eastward and exit at the Nakadake crater (Fig. 12). Tsutsui et al. (2003) observed a high-velocity zone considered to be a dike or dense volcanic deposits beneath Kusasenrigahama to the Nakadake crater; therefore, magma from a magma storage region could not ascended directly above this area. Yamamoto et al. (1999) showed a dike model conduit beneath the Nakadake craters with a reasonable dip range of $83^{\circ}-86^{\circ} \mathrm{W}$. This dike probably has been created by connection faulting between Aso-N.C and Aso-S by westward dragging.

In the NM-RCZ, disconnected and echelon-distributed small ruptures were found along the recent magmatic vents. We detect a small rupture of $80^{\circ}$ dip in the outcrop toward the south at Site 6 that indicates propagation with $80^{\circ}-85^{\circ}$ dip of these fractures close to the probably north side of magma storage region. Meanwhile, we have a problem why geothermal activities such as fumaroles or hot springs occur only on Aso-S rupture band 


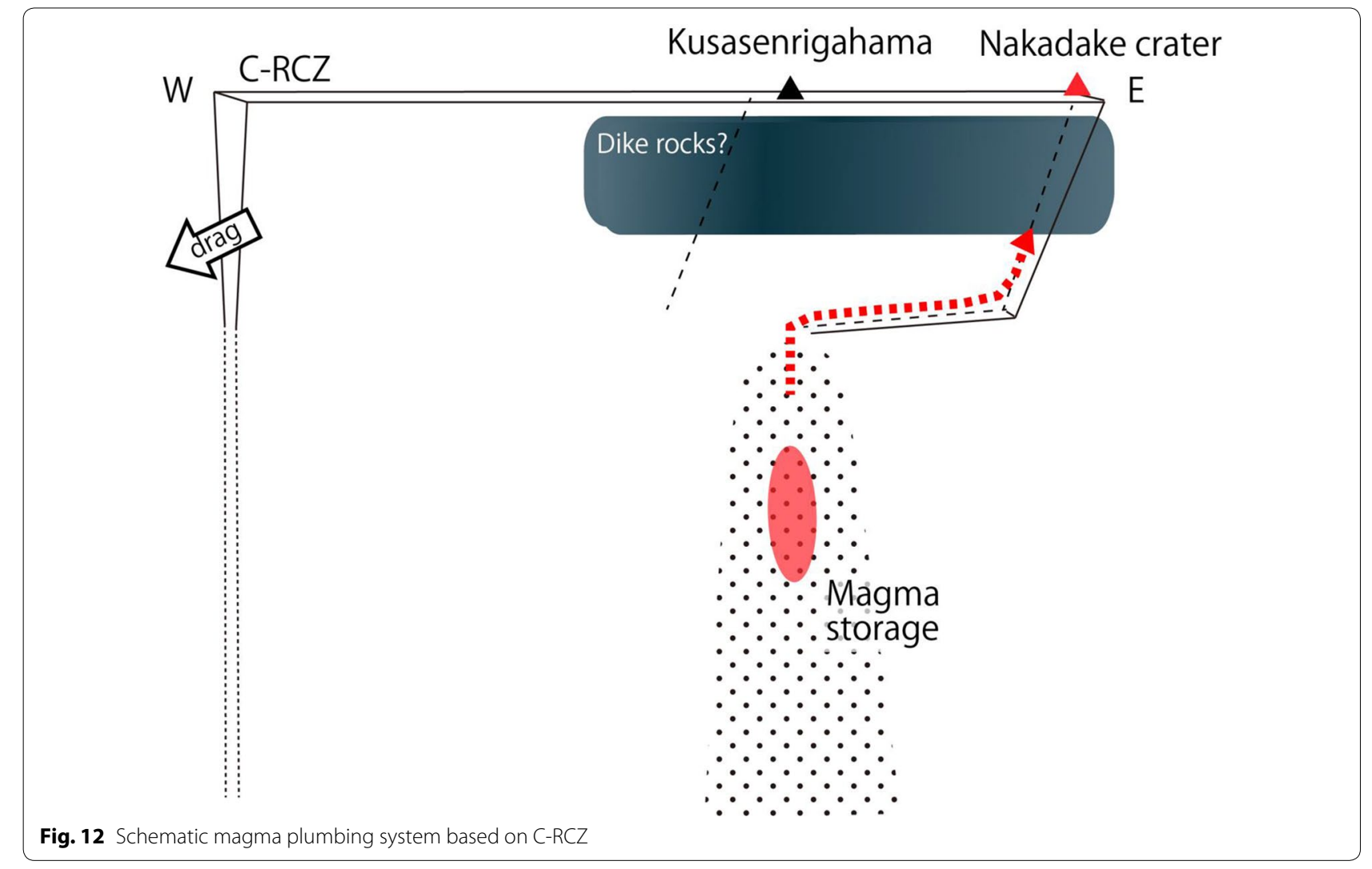

as Yunotani and Yoshioka fumaroles. We need to make a whole model of plumbing system including geothermal system for central cones of Aso volcano.

The bend texture of normal faulting in the Yoshioka area indicates a drag to the west. These observations are consistent with ground movement reported by Fujiwara et al. (2016). Matsuda (1974) identified terminal bulge deformation from the Nobi earthquake in 1891 as left lateral slip. We considered possibility for the generation of RCZ as the terminal texture of the extensional graben from Kawayo to the Kusasenrigahama crater (Kp). However, detailed geological and geophysical observations are needed to determine the generation mechanism and long-term activity of the RCZ.

\section{Conclusions}

We observed abundant earthquake ruptures and landslides on Aso volcano. The geomorphological variations caused by the Kumamoto earthquakes created an RCZ with a core composed of Aso-N, Aso-C, and Aso-S rupture bands. It was inferred that the Aso-S rupture band extended to the north Hinoyama tunnel and that Aso- $\mathrm{N}$ and Aso-C rupture bands extended to the north Kusasenrigahama area. We observed parallel lines of rupture band as fault structures that were assumed by drag extensional faulting by the Futagawa faults. We found a strong relationship between the locations of volcanic vents and fault structures on the central cones of Aso volcano. In particular, very strong agreement was indicated between the distribution of recent magmatic vents and the NM-RCZ. Additionally, the Nakadake crater correlates with the C-RCZ. These results indicate a strong correlation between the major faulting and volcanic activity in Aso volcano.

\section{Author details}

${ }^{1}$ Nippon Koei Co., Ltd., 2-17-14, Higashisakura, Higashi-ku, Nagoya 461-0005, Japan. ${ }^{2}$ Graduate School of Science and Technology, Faculty of Science, Kumamoto University, 2-39-1 Kurokami, Chuo-ku, Kumamoto 860-8555, Japan. ${ }^{3}$ Implementation Research and Education System Center for Reducing Disaster Risk (IRESC), Graduate School of Science and Technology, Kumamoto University, 2-39-1, Kurokami, Chuo-ku, Kumamoto 860-8555, Japan.

\section{Authors' contributions}

All authors contributed to the field survey of landslides or faults. YT created distribution maps of faults and landslides by using Google Earth or aerial photographs and drafted the manuscript. TH helped with field work and sample identification. MT helped to decipher the images. All authors read and approved the final manuscript.

\section{Acknowledgements}

The authors thank K. Ishihara and M. Hannah for offering helpful comments. In addition, the authors thank Y. Miyabuchi for providing age data and A. Terada for providing fumarole activity information for Yoshioka of Aso volcano. Many 
associates are thanked for providing access to the pasture area. This manuscript was improved by considering the helpful comments of R. Sulpizio and an anonymous reviewer and editors.

\section{Competing interests}

The authors declare that they have no competing interests.

\section{Publisher's Note}

Springer Nature remains neutral with regard to jurisdictional claims in published maps and institutional affiliations.

Received: 9 August 2016 Accepted: 14 April 2017

Published online: 02 May 2017

\section{References}

Corti G, Sani F, Philippon M, Sokoutis D, Willingshofer E, Molin P (2013) Quaternary volcano-tectonic activity in the Soddo region, western margin of the Southern Main Ethiopian Rift. Tectonics 32:861-879. doi:10.1002/ tect.20052

Fujiwara S, Yarai H, Kobayashi T, Morishita Y, Nakano T, Miyahara B, Nakai H, Miura Y, Ueshiba H, Kakiage Y, Une H (2016) Small-displacement linear surface ruptures of the 2016 Kumamoto earthquake sequence detected by ALOS-2 SAR interferometry. Earth Planets Space 68:160. doi:10.1186/ s40623-016-0534-x

Geospatial Information Authority of Japan (1994) ASOSAN, 1:30,000 Volcanic land condition map. http://www.gsi.go.jp/bousaichiri/volcano-mapsvlcm.html. Accessed 30 July 2016

Geospatial Information Authority of Japan (2016) http://www.gsi.go.jp/BOUSAl/H27-kumamoto-earthquake-index.html. Accessed 30 July 2016

Google Earth @ 2016 ZENRIN (2016) Opened 16 April 2016. Accessed 30 July 2016

Headquarters for Earthquake Research Promotion (2002) http://www. jishin.go.jp/main/chousa/katsudansou_pdf/93_futagawa_hinagu.pdf. Accessed 30 July 2016

Headquarters for Earthquake Research Promotion (2016) http://www.static. jishin.go.jp/resource/monthly/2016/2016_kumamoto_3.pdf. Accessed 30 July 2016

Ikebe S, Fujioka M (2001) "Yunotani catastrophe" of 1816, in Aso volcano, southwest Japan-historical records of steam explosion. Bull Volcanol Soc Jpn 46:147-163. doi:10.18940/kazan.46.4_147

Japan Meteorological Agency (2013) Asosan. In: Hoshizumi H, Miyabuchi Y (eds) National catalogue of the active volcanoes in Japan, 4th edn, pp 1-37. http://www.data.jma.go.jp/svd/vois/data/tokyo/STOCK/souran_ eng/souran.htm\#tyugoku. Accessed 30 July 2016

Karakhanian A, Djrbashian R, Trifonov V, Philip H, Arakelian S, Avagian A (2002) Holocene-historical volcanism and active faults as natural risk factors for Armenia and adjacent countries. J Volcanol Geotherm Res 113:319-344. doi:10.1016/S0377-0273(01)00264-5

Mannen K (2008) Hakone caldera: structure, mode of formation, and role in present-day volcanism. Res Rep Kanagawa Prefect Mus Nat Hist 13:61-76

Matsuda T (1974) Surface faults associated with Nobi (Mino-Owari) earthquake of 1981, Japan. Specif Rep Earthq Res Inst 13:85-126

Matsumoto A, Uto K, Ono K, Watanabe K (1991) K-Ar age determinations for Aso volcanic rocks - concordance with volcanostratigraphy and application to pyroclastic flows. In" programme and abstracts the volcanological society of Japan, no. 2, p 73

Miyabuchi Y (2009) A 90,000-year tephrostratigraphic framework of Aso Volcano, Japan. Sediment Geol 220:169-189. doi:10.1016/j. sedgeo.2009.04.018

Miyabuchi Y (2010) Eruption age of Komezuka at Aso volcano, Japan. Bull Volcanol Soc Jpn 55:219-225. doi:10.18940/kazan.55.5_219

Miyabuchi Y (2016) Landslide disaster triggered by the 2016 Kumamoto earthquake in and around Minamiaso village, western part of Aso caldera, southwestern Japan. J Geogr (Chigaku Zasshi) 125:421-429. doi:10.5026/ jgeography. 125.421
Miyabuchi Y (2017) Eruption history of Janoo Volcano in the northwestern part of Aso caldera, Japan. Bull Volcanol Soc Jpn 62:1-12. doi:10.18940/ kazan.62.1_1

Miyabuchi Y, Watanabe K (1997) Eruption ages of Holocene tephras from Aso volcano, southwestern Japan, inferred from ${ }^{14} \mathrm{C}$ ages of buried andisols. Bull Volcanol Soc Jpn 42:403-408. doi:10.18940/kazan.42.6_403

Miyabuchi Y, Watanabe K (2000) Phreatic explosion and ejecta around Jigoku Spa, southwestern part of central cones of Aso volcano, Japan. Bull Volcanol Soc Jpn 45:25-32. doi:10.18940/kazan.45.1_25

Miyabuchi Y, Hoshizumi H, Watanabe K (2004a) Late-pleistocene tephrostratigraphy of Aso volcano, southwestern Japan, after deposition of AT ash. Bull Volcanol Soc Jpn 49:51-64. doi:10.18940/kazan.49.2_51

Miyabuchi Y, Masuda N, Watanabe K (2004b) Geologic history of the western part of post-caldera central cones of Aso volcano, southwestern Japan, based on stratigraphic relationships between lava flows and airfall tephra layers. Bull Volcanol Soc Jpn 49:267-282. doi:10.18940/kazan.49.5_267

Nakamura K (1969) Arrangement of parasitic cones as a possible key to regional stress field. Bull Volcanol Soc Jpn 14:8-20

Okuno M (2011) Establishment of a high-resolution tephro-stratigraphy and chronology based on geological survey. J Geol Soc Jpn 117:654-662. doi:10.5575/geosoc.2011.0003

Okuno M, Nakamura T (2003) Radiocarbon dating of tephra layers: recent progress in Japan. Quat Int 105:49-56. doi:10.1016/S1040-6182(02)00150-7

Ono K, Watanabe K (1985) Geological map of Aso Volcano. Geological map of volcanoes 4, Geological survey of Japan

Ono K, Watanabe K, Hoshizumi H, Takada H, Ikebe S (1995) Ash eruption of Nakadake volcano, Aso caldera, and its products. Bull Volcanol Soc Jpn 40:133-151. doi:10.18940/kazan.40.3_133

Research group for active tectonics in Kyushu (1989) Active tectonics in Kyushu. University of Tokyo Press, Tokyo

Shirahama Y, Yoshimi M, Awata Y, Maruyama T, Azuma T, Miyashita Y, Mori H, Imanishi K, Takeda N, Ochi T, Otsubo M, Asahina D, Miyakawa A (2016) Characteristics of the surface ruptures associated with the 2016 Kumamoto earthquake sequence, central Kyushu, Japan. Earth Planets Space 68:191. doi:10.1186/s40623-016-0559-1

Sudo Y, Kong LSL (2001) Three-dimensional seismic velocity structure beneath Aso Volcano, Kyushu, Japan. Bull Volcanol 63:326-344. doi:10.1007/ s004450100145

Takahashi M (1995) Large-volume felsic volcanism and crustal strain rate. Bull Volcanol Soc Jpn 40:33-42. doi:10.18940/kazan.40.1 33

Terada A, Sudo Y, Yoshikawa S, Inoue H (2007) Quantitative analysis of geothermal events at the Yoshioka hot spring, Aso volcano, in 2006. Bull Volcanol Soc Jpn 52:335-340. doi:10.18940/kazan.52.6_335

Tsutsui T, Sudo Y, Mori T, Katsumata K, Tanaka S, Oikawa J, Tomatsu T, Matsuwo N, Matsushima T, Miyamachi H, Nishi K, Fujiwara Y, Hiramatsu H (2003) 3-D seismic velocity structure beneath the edifice of central cones of Aso Volcano. Bull Volcanol Soc Jpn 48:293-307. doi:10.18940/kazan.48.3_293

U.S. Geological Survey (2004) Landslide types and processes. USGS Fact Sheet 2004-3072, July 2004, U.S. Department of the Interior, U.S. Geological Survey, http://pubs.usgs.gov/fs/2004/3072/. Accessed 30 July 2016

Varnes DJ (1978) Slope movement types and processes. In: Schuster RL, Krizek RJ (eds) Landslides-analysis and control: National Research Council, Washington, D.C., Transportation Research Board, Special Report 176, pp 11-33

Watanabe K (2001) History and activity of Aso volcano (Japanese title "Aso kazan no oitachi"). Ichinomiya-cho

Watanabe K, Ono K (1969) Geology of the vicinity of Omine on the western flank of the Aso caldera. J Geol Soc Jpn 75:365-374. doi:10.5575/ geosoc.75.365

Watanabe K, Momikura Y, Tsuruta K (1979) Active faults and parasitic eruption center on the west flank of Aso Caldera, Japan. Quat Res (Daiyonki Kenkyu) 18:89-101. doi:10.4116/jaqua.18.89

Yamamoto M, Kawakatsu H, Kaneshima S, Mori T, Tsutsui T, Sudo Y, Morita Y (1999) Detection of a crack-like conduit beneath the active crater at Aso volcano. Geophys Res Lett 26:3677-3680. doi:10.1029/1999GL005395 